\title{
THE ECONOMICS OF FISH FARMING IN JORDAN
}

(Received: 23.3.2016)

\author{
By \\ J. A. Al-Dala'een \\ Agricultural Economics, Karak University College, Balqa Applied University, Jordon
}

\begin{abstract}
The production of fish started as a series of experiments to test the correct methods and procedures of fish production in Jordan. Fish marketing is a very sophisticated process related to the nature of the product. Most farmers indicated that marketing problem is one of the major problems that faces fish production in Jordan. The paper recommends many steps to be taken to improve fish farming in Jordan. The first and vital, is increasing scientific research related to fish production in Jordan to determine the best conditions, type of fingerlings, diseases and the best methods to treat these diseases. Holding seminars and workshops for farmers interested in fish farming in Jordan is important to educate them about fish farming and the right procedures that should be used and increasing awareness about economics of fish production in Jordan.
\end{abstract}

Key words: fish, economy of production, shortages.

\section{INTRODUCTION}

Fish farming is one of the agricultural activities that started to spread in late years (Olaoye et al., 2013). The fishing sector in some countries contributes in enlarging the agriculture labor force (New Partnership for African Development, 2005). The number of fish farms worldwide increased gradually despite the local experience of fish farming is still restricted (FAO, 2014). Most of the starting farms depended on foreign experiences or the Egyptian experience in fish farming.

Fish farming faced many problems which are related to the type of fish that matches the environmental conditions in Jordan, the availability of proper water quality that matches fish farming (Hamidan, 2014), the availability of fodder, and the availability of fingerlings for farming activities. The Jordanian fish sector lacks the experience related to fish disease and the proper methods of treatment. The high expenses of fish farming maintenance make it difficult to develop fish farming in Jordan (FAO, 2003).

Most of the existing farms still have restricted production volume, which decline the feasibility of fish farming in these farms. The restricted production resulted from the different difficulties that face fish farming. These difficulties made most of farmers hesitate to practice this new activity at large scale. The failure of some farmers in practicing fish farming discouraged the other farmers to join. The emotional aspect in this respect played a major role in removing many farmers from fish farming section. The lack of financial capabilities of some farmers was another restriction that made these farmers give up such activity.

The formal interest of fish farming, on the other side, is still limited. Consequently, the encouragement received by farmers to practice fish farming is restricted. The governmental capabilities to support fish farming are restricted as well. Such difficulties made the private sector tolerating the side effects of the adventure alone. None of the farmers had the tendency to try any agricultural activity if they failed once. Fish farming sector should receive more care from the government and the private sector to make it more organized and dependent on strong basis to help farmers stand a feasible production.

Most of fish farmers depend on the experience of others and none of them studied fish farming per se. Most of the efforts in this respect are concentrated on the collection of information from scattered sources. Thus examining the distribution of fish farming in Jordan according to scientific and previously studied situations and conditions will help in providing the requirements and guidance 
required. This will help provide the inputs and the required machinery with feasible prices in the Jordanian market.

This paper was designed to introduce information about fish farming in Jordan. It summarizes the difficulties that face this activity and explain the need for such activity in a country like Jordan.

\subsection{Fish production and consumption patterns in Jordan}

Marine fish production is limited in Jordan because of the limited coasts. The production of marine fish is limited to Aqaba city in southern Jordan. The production of fish is less than the demand on sea products. Self-sufficiency ratio (SSR) is considered very low, reflecting the low production and high demand on fish in the Jordanian market. The highest SSR rate was recorded in 2013 with percentage reaching $6.81 \%$, while the least SSR was in 2011 with $3.04 \%$. The results showed that the production of fish is increasing over years due to the increase of the number of fisheries in Jordan.

The fluctuation in production exports and imports over years is a result of lack of national strategy for the arrangement of this sector as the concern with this sector started since 2008. The formal parties are still trying to collect information about this sector with the lack of national strategies and policies to improve it. The increase of the number of fisheries is limited due to the lack of encouragement of the private sector to invest in this sector. the types of fish that were raised in Jordan, the availability of water for fish farming and any other related information.

The primary data were collected through a questionnaire prepared for the purpose of this paper. The questionnaire included 69 paragraphs asking about fish farming in Jordan. The sample selected included 106 holders. These holders included fish farms, farms practicing fish raising as part of its activities, and holders that do not practice fish farming. The purpose of including these three categories of holders is to collect information about the existing fish farms and seeking the point of view of other holders regarding fish farming advantages and disadvantages in Jordan. The included questions were expected to help building recommendations that help in improving fish farming activities in Jordan.

The prepared questionnaire included questions that collect information about the experience in fish farming, the common types of fish raised in fish farms, the advantages and disadvantages of each type, the difficulties that face fish farming in Jordan, the feasibility of fish farms and the possibility for holders to practice fish farming if the difficulties will be solved.

Table (2) shows the distribution of fish producing farms in Jordan. The table represents the organized fish production sector. The highest number of farms is found in the middle region with 19 farms, while the least number of

Table (1): Production, exports, imports, SSR of fish in Jordan.

\begin{tabular}{|l|l|l|l|l|l|l|l|}
\hline Year & $\begin{array}{l}\text { Production } \\
\text { (ton) }\end{array}$ & Change & $\begin{array}{l}\text { Exports } \\
\text { (ton) }\end{array}$ & Change & $\begin{array}{l}\text { Imports } \\
\text { (ton) }\end{array}$ & Change & $\begin{array}{l}\text { Self } \\
\text { Sufficiency } \\
\text { Ratio }\end{array}$ \\
\hline 2008 & 904 & & 1927 & & 26180 & & 3.73 \\
\hline 2009 & 1010 & 11.72 & 3810 & 97.72 & 28253 & 7.91 & 4.13 \\
\hline 2010 & 1023 & 1.29 & 1653 & -56.61 & 23273 & -17.63 & 4.73 \\
\hline 2011 & 1075 & 5.08 & 2667 & 61.34 & 37983 & 63.21 & 3.04 \\
\hline 2012 & 1248 & 16.09 & 4519 & 69.44 & 31869 & -16.10 & 4.56 \\
\hline 2013 & 1233 & -1.20 & 1954 & -56.76 & 20048 & -37.09 & 6.81 \\
\hline 2014 & 1144 & -7.22 & 705 & -63.92 & 28358 & 41.45 & 4.14 \\
\hline 2015 & 1312 & 14.69 & 1452 & 105.96 & 31235 & 10.15 & 4.41 \\
\hline
\end{tabular}

Source: National Strategy Surveys for Agricultural Development, 2008-2016, Department of Statistics, Amman, Jordan.

\section{METHODOLOGY}

Two approaches were used to collect the data. The first approach used the secondary data sources that relied on the available sources that discuss or introduce information about fish farming in Jordan. The collected data included farms is located in the southern region with only one farm. The distribution of farms in these areas may be a result of the availability of water required for fish production. In other areas of Jordan, the availability of water for such purposes is less or its price is higher, so the production cost will be high too. 
Table (2): The distribution of producing farms in 2015.

\begin{tabular}{|l|l|}
\hline Location & Number of farms \\
\hline North region & 12 \\
\hline Middle region & 21 \\
\hline South region & 1 \\
\hline Total & 34 \\
\hline
\end{tabular}

Source: Department of Statistics, (2015).

Animal Production Division, Amman, Jordan

Fish of domestic production (comb and anguish) sold either from the farm or through a scavenger fish distributed to the houses by private cars in refrigerated form. Also, the fish are distributed to supermarkets deployed in the capital. The live fish are sold to restaurants where there are small ponds. Fish are cooked directly and sold in these restaurants. Sale prices ranged from JD 2.5-3.75 per kilogram, while a meal is sold in the restaurant at JD 8 per person.

With regard to the imported frozen fish, prices are ranging from JD 1.2 up to JD 5.5 per $\mathrm{kg}$, while for the fresh imported fish, price ranges from JD 3.5 per $\mathrm{kg}$ to JD 18 per $\mathrm{kg}$ of the types of salmon.

\section{RESULTS AND DISCUSSION}

3.1. Distribution and characteristics of sample

Field survey was run in four governorates in Jordan which have fish farming activities. These governorates are Al Karak, Irbid, Ajloun and Balqa. The results showed that the highest distribution of holders is in $\mathrm{Al}$ Karak governorate with a frequency of 66 and percentage $62.3 \%$. The second ranked is Balqa governorate with a frequency of 23 and percentage $21.7 \%$ of the sample. The collected sample included both farmers that practice fish farming or not. The cause of such selection was to discuss the fish farming with the two categories in order to determine the obstacles that face fish production in Jordan (Table 3).

Table (3): The distribution of the studied sample.

\begin{tabular}{|l|c|c|}
\hline Governorate & Frequency & Percentage \\
\hline Al Karak & 66 & 62.3 \\
\hline Irbid & 16 & 15.1 \\
\hline Ajloun & 1 & 0.9 \\
\hline Balqa & 23 & 21.7 \\
\hline
\end{tabular}

The results in Table (4) show the distribution of holdings in the collected sample according to villages. The results show that the highest concentration of holdings was in Ghor Al Saffi with a frequency of 38 and a percentage of $36.5 \%$ of the sample. The other places that contained higher holdings with the highest percentage were Ghor Al Hadeethi, South Shouna, North Shouna, Ghor Al Mazraha and Deir Alla. All the previous locations are part of the Jordan valley. This indicated that the number of holdings in the sample that are located in the Jordan valley is 90 with a percentage $84.9 \%$. The concentration of the farms in Jordan valley resulted in the concentration of fish production in the valley.

Table (4): The distribution of fish farmers on The study villages.

\begin{tabular}{|l|c|c|}
\hline Village name & Frequency & Percentage \\
\hline Alssafi & 38 & 36.54 \\
\hline Ghor Al Hadeethi & 11 & 10.58 \\
\hline Ghor Al Mazzrah & 9 & 8.66 \\
\hline Al Baqooreh & 2 & 1.92 \\
\hline Ql Quwaismeh & 1 & 0.96 \\
\hline Ein Al Barakeh & 1 & 0.96 \\
\hline Deir Alla & 9 & 8.65 \\
\hline South Shoona & 11 & 10.58 \\
\hline Kafrain & 1 & 0.96 \\
\hline North Shoona & 12 & 11.54 \\
\hline Al Mashare' & 3 & 2.88 \\
\hline $\begin{array}{l}\text { Ghor Al Hadeetha } \\
\text { and Al Mazzra }\end{array}$ & 6 & 5.77 \\
\hline
\end{tabular}

Table (5) shows the distribution of activities of the holdings. The results show that $61.4 \%$ of holders are planting vegetables. In the second rank is the fish farming with a percentage $21.97 \%$, followed by the fruit production with a percentage of $15.91 \%$. The rank of fish farming and its percentage indicate the desire of farmers to produce fish, but the difficulties of production form an obstacle that limits the spread of fish farming activities.

Table (5): The distribution of fish farming compared to other activities among the study sample.

\begin{tabular}{|l|l|l|}
\hline Type of farm & Frequency & Percentage \\
\hline Vegetables & 81 & 61.36 \\
\hline Nursery & 1 & 0.76 \\
\hline Fruit trees & 21 & 15.91 \\
\hline Fish farms & 29 & 21.97 \\
\hline
\end{tabular}

The results in Table (6) show the number of holders that practice fish farming in their farms. 
The results show that about 42 holders practice fish farming in their farms with a percent of $41.2 \%$. This indicates that the practice of fish farming is considered one of the activities existed in the farm but not the major one. The difficulties existed in fish production in Jordan lead to such satisfaction about fish farming.

Table (6): Practice fish farming.

\begin{tabular}{|l|l|l|}
\hline $\begin{array}{l}\text { Practice fish } \\
\text { farming }\end{array}$ & Frequency & Percentage \\
\hline Yes & 42 & 41.2 \\
\hline No & 60 & 58.8 \\
\hline
\end{tabular}

Table (7) explains the causes of farmers to practice fish farming in their farms. The highest percentage of farmers considered fish farming as a source to increase their income. The percentage of these farmers reached $46.0 \%$, while $19.0 \%$ of farmers considered it as a hobby practiced by them in their farms.

Other farmers indicated that fish is considered a good tool to eliminate the algae in ponds to decrease the irrigation pipes clogging, while the others considered it as a source of food for the family and the rest of farmers have different causes such as the existence of water or saline water. the other agricultural activities that provide about $67.12 \%$ of farmer income (Table 8 ).

Table (8): The number of holders that depended on fish farming as one of income sources.

\begin{tabular}{|l|l|l|}
\hline Activity & Frequency & Percentage \\
\hline Agriculture & 98 & 67.12 \\
\hline Governmental career & 15 & 10.27 \\
\hline Pension & 14 & 9.59 \\
\hline Industry & 1 & 0.69 \\
\hline Trade & 5 & 3.42 \\
\hline Fish farming & 12 & 8.22 \\
\hline Bees raising & 1 & 0.69 \\
\hline
\end{tabular}

\subsection{Source of water for fish farming}

The majority of samples indicated that farmers get water needed to practice fish farming in their farms through the tankers. The number of these farmers reached 63 with a percentage of $60.0 \%$. The second source of water was King Abdulla Channel with 22 farmers and a percentage $20.95 \%$ of the sample (Table 9). The first used source is considered expensive. This source will form overburden for the farmer engaged in fish production purposes. This explains why farmers practice fish production as a subsidiary activity in their farms. This is because if fish production will be the first

Table (7): The causes of practicing fish farming.

\begin{tabular}{|l|l|l|}
\hline Cause & Frequency & Percentage \\
\hline Increasing income & 29 & 46.0 \\
\hline Using the fish residues for vegetables & 3 & 4.8 \\
\hline Hobby & 12 & 19.0 \\
\hline Family source of food & 6 & 9.5 \\
\hline Elimination of algae in pond & 9 & 14.3 \\
\hline Presence of spring & 2 & 3.2 \\
\hline The saline wells water help in fish farming & 2 & 3.2 \\
\hline
\end{tabular}

The experience of the farmers in fish production is low, as the average experience of the farmers in fishing is 4.4 years. This time is considered not enough to build high experience in fish production under local production conditions. This justifies the low reliability on fish farming as a major source of income for the farmers. The contribution of fish farming in farmers' income did not exceed $8.22 \%$. This percentage is considered low if farmers are considering fish farming as a major activity in their farms. The major activity for farmers was activity, the amounts of water required will be very high and so the inputs cost.

Table (9): The source of water used for fish farming in the study sample.

\begin{tabular}{|l|l|l|}
\hline Source & Frequency & Percentage \\
\hline King Abdulla Channel & 22 & 20.95 \\
\hline Springs & 7 & 6.67 \\
\hline Tankers & 63 & 60.00 \\
\hline Water Authority water & 7 & 6.67 \\
\hline Jordan Valley Authority & 6 & 5.71 \\
\hline
\end{tabular}


Table (10) shows that 64 farmers use fresh water for fish farming with a percentage $65.98 \%$. This result is comparable with the previous results as 63 of farmers are using tankers. About 31 farmers with a percentage $31.96 \%$ indicated that they use mixed water for fish production, while only 2 farmers with a percentage $2.06 \%$ indicated that they use saline water for fish production.

Table (10): The quality of water used for fish farming.

\begin{tabular}{|l|l|l|}
\hline Quality of water & Frequency & Percentage \\
\hline Fresh water & 64 & 65.98 \\
\hline Mixed water & 31 & 31.96 \\
\hline Saline water & 2 & 2.06 \\
\hline
\end{tabular}

The quantity of water used varied according to the quality of water. The highest amount of water used is from the saline water. The quantity used was $45666 \mathrm{~m}^{3}$ which are four folds the quantity of fresh water used; 14841 $\mathrm{m} 3$. The usage of high quantities of saline water compared to fresh water can be explained by the price of water. The price of saline water is much less than the fresh water which are brought by tankers. As a result, the quantity used should be lower from fresh water in order to decrease the cost of production. Moreover, saline water can be used only for fish production, while the fresh water are used for other agricultural activities after being used for fish production.

Most farmers showed that they change the water every three days and not daily. The number of farmers that indicated that fact is 27 with a percentage of $84.4 \%$. Only five farmers indicated that they change the water on a daily basis. This is related to the previous explained factors concerning prices and cost of production (Table 11).

\subsection{Cost of inputs}

Only three farmers indicated that they have fish hatchers with a cost JD 4733 per one and the running cost is JD 750. The rest of farmers are not hatchers. This proved that most of farmer practice fish farming as a second activity.

About 38 farmers with a percent of $82.6 \%$ indicated that they are using the common culture methods to produce fish. This high percentage explained that most of farmers were looking for cheap methods of production to decrease the production costs. Only 4 farmers indicated that they use the concentrated method or the concentrated net method for production (Table 12).

Table (12): Methods of breeding.

\begin{tabular}{|l|l|l|}
\hline Method & Frequency & Percentage \\
\hline Concentrated & 4 & 8.7 \\
\hline Concentrated net & 4 & 8.7 \\
\hline Common & 38 & 82.6 \\
\hline
\end{tabular}

Only 14 farmers indicated that they use fiberglass ponds to breed fish. The cost of this method justifies its low number of farmers. The cost of this system is JD 15,250, which is higher than the other two methods. The number of farmers indicated that they use cement ponds is 3 and the average cost of cement ponds is JD 70.50 The number of farmers that use silt ponds is 2 and the average cost of earthen pond is JD 17.64 (Table 13).

The average of the total quantity of fish produced in fiberglass ponds was $153000 \mathrm{~kg}$ which was very high compared to the other

Table (11): Characteristics of used water.

\begin{tabular}{|l|l|l|l|l|l|l|}
\hline Characteristics of used water & Fresh & & Mixed & & Saline Water & \\
\hline Average of used quantity & 14841 & & 4950 & & 45666 & \\
\hline Price $/ \mathrm{m}^{3}$ & 2 & & 1.48 & & & \\
\hline Period of changing water & Freq. $^{*}$ & Per. $^{* *}$ & Freq. & Per. & Freq. & Per. \\
\hline Every three days & 27 & 84.4 & 3 & 27.3 & 1 & 33.3 \\
\hline Daily & 5 & 15.6 & 8 & 72.7 & 2 & 66.7 \\
\hline Problems of water & & & & & & \\
\hline Weak water & 4 & 100 & & & & \\
\hline Purity of water & & & 6 & 100 & & \\
\hline
\end{tabular}

\footnotetext{
* Freq. $=$ Frequency
}

** Per.= Percentage 
Table (13): The characteristics, cost and income of fish farming.

\begin{tabular}{|l|l|l|l|l|}
\hline Type of breeding & $\begin{array}{l}\text { Area allocated } \\
\text { (dunums) }\end{array}$ & $\begin{array}{l}\text { Average } \\
\text { cost }(\mathbf{J D})\end{array}$ & $\begin{array}{l}\text { Average of production } \\
\text { quantity }(\mathbf{k g})\end{array}$ & $\begin{array}{l}\text { Average of water } \\
\text { quantity used }\left(\mathbf{m}^{3}\right)\end{array}$ \\
\hline Cement ponds & 3 & 7.050 .0 & 1.0743 & 8.800 \\
\hline Fiber glass ponds & 14 & 15.250 .0 & 1.53000 & 15.000 \\
\hline Earthen ponds & 2 & 1.764 .7 & 5.794 & 1.900 \\
\hline
\end{tabular}

methods. This explained the high quantity of water used in this method of culture which reached $15.000 \mathrm{~m}^{3}$. The average production of fish when using cement ponds was $10.743 \mathrm{~kg}$ and the amount of water used was $8.800 \mathrm{~m}^{3}$. The least production existed in the earthen ponds as the average quantity produced was $5794 \mathrm{~kg}$ with the amount of water used was $1.900 \mathrm{~m}^{3}$.

\subsection{Breeding species}

In the study sample, three fish species were recorded. These three species were Tilapia (Tilapia zillii), Orea (Oreochromis aureus) and Carp (Cyprinus carpio). Most of farmers use these species for fish production in Jordan. Tilapia is found to be the most common species compared to the other two species. Table (14) explained the advantages of Tilapia culture. The results showed that 22 farmers with a percent of $23.2 \%$ indicated that the breeding is simple. The other major advantage of breeding Tilapia culture is its tolerance to diseases. The number of farmers agreed on that fact was 20 with a
$21.1 \%$ of the sample. The favored taste of Tilapia is considered one of the factors that made this species common among farmers. The number of farmers which indicated that was 25 with $26.3 \%$ of the sample.

Also, the results indicated that Tilapia tolerate weather conditions. The good growth rate in weight of Tilapia makes it a favorable species among farmers. All the previous conditions indicated that Tilapia is more suitable for fish production in Jordan.

Concerning the disadvantage of Tilapia culture, the sample showed some disadvantages but with less agreement on it compared to advantages. Some farmers showed that the marketing problem could be considered one of the disadvantages of producing Tilapia (Table 15).

The other disadvantages varied, including lack of fodder, problems in irrigation, logging of irrigation pipes, lack of tolerance of cold weather, low productivity and lack of variety of Tilapia species.

Table (14): The advantages of Tilapia culture in Jordan.

\begin{tabular}{|l|l|l|}
\hline Tilapia feature & Frequency & Percentage \\
\hline Simple breeding & 22 & 23.16 \\
\hline Tolerate quality problems & 1 & 1.05 \\
\hline Tolerate weather conditions & 8 & 8.42 \\
\hline Favored taste & 25 & 26.32 \\
\hline Fertilizer residues for land & 1 & 1.05 \\
\hline Good growth rate & 9 & 9.47 \\
\hline Tolerate diseases & 20 & 21.06 \\
\hline Suitable for the area & 5 & 5.26 \\
\hline Proper sizes & 1 & 1.05 \\
\hline Tolerate salinity & 2 & 2.11 \\
\hline Killing fungi & 1 & 1.05 \\
\hline
\end{tabular}


Table (15): The disadvantages of Tilapia culture in Jordan.

\begin{tabular}{|l|l|l|}
\hline \multicolumn{1}{|c|}{ Feature } & Frequency & \multicolumn{1}{c|}{ Percentage } \\
\hline Lack of fodder & 2 & 6.90 \\
\hline Problems in irrigation & 2 & 6.90 \\
\hline Lack of number matching & 1 & 3.45 \\
\hline Logging or pipes due to fodder & 2 & 6.90 \\
\hline Marketing problems & 9 & 31.03 \\
\hline Does not tolerate cold weather & 2 & 6.90 \\
\hline High fodder prices & 1 & 3.44 \\
\hline Price problem & 1 & 3.44 \\
\hline Low productivity & 2 & 6.90 \\
\hline Small size & 1 & 3.44 \\
\hline Fungi & 1 & 3.45 \\
\hline Unclean water & 1 & 3.45 \\
\hline Vicious at harvesting & 1 & 3.45 \\
\hline Weather & 1 & 3.45 \\
\hline Lack of variety of species & 2 & 6.90 \\
\hline
\end{tabular}

Table (16) showed the distribution of Tilapia, Oreo and Carp in fish culture in the study sample. The results indicated that Tilapia was the most common type of fish used. The average quantity raised is $12716.3 \mathrm{~kg}$, compared to $2.560 \mathrm{~kg}$ for Oreo and $2035 \mathrm{~kg}$ for Carp. The first ranked source of Tilapia was Egypt. The number of farmers that indicated the import of Tilapia from Egypt was 19 with a percentage of $43.2 \%$. The local sources were distributed among the cooperative societies with a frequency of 12 and $27.3 \%$, and the Hashemite Box with a frequency of 6 and a percent of $13.6 \%$.
The source of the other two types of fish (Oreo and Carp) was Egypt only. These types of fish existed in one farm only. The quantity produced from Tilapia was very high compared to the other two types (Table 16).

\subsection{Fodder management}

Table (17) showed the type of fodder used in fish farming in the studied sample. The results show that 37 farmers were using the concentrated fodder with a percentage of $78.72 \%$. Nine farmers indicated that they were using floated fodder with a percent of $19.15 \%$. Only one farmer indicated the usage of mixture (32\% protein) fodder for fish production. This

Table (16): The distribution of breeding species and its characteristics.

\begin{tabular}{|c|c|c|c|c|c|c|c|}
\hline \multicolumn{2}{|c|}{ Feature } & \multicolumn{2}{|c|}{ Tilapia } & \multicolumn{2}{|c|}{ Oreo } & \multicolumn{2}{|c|}{ Carp } \\
\hline \multicolumn{2}{|c|}{ Average of raised quantity $(\mathrm{kg})$} & \multicolumn{2}{|c|}{12716.3} & \multicolumn{2}{|c|}{2560} & \multicolumn{2}{|c|}{2035} \\
\hline \multicolumn{2}{|c|}{ Monosex } & \multicolumn{2}{|c|}{36} & \multicolumn{2}{|c|}{ 78.3\% } & \\
\hline \multirow[t]{2}{*}{ Non-monosex } & Frequency & \multicolumn{2}{|l|}{10} & \multicolumn{2}{|l|}{1} & \multicolumn{2}{|l|}{2} \\
\hline & Percentage & 21.7 & & 100 & & 100 & \\
\hline \multicolumn{2}{|c|}{ Source } & Freq. & Per. & Freq. & Per. & Freq. & Per. \\
\hline \multicolumn{2}{|c|}{ Hashemite Box } & 6 & 13.6 & & & & \\
\hline \multicolumn{2}{|c|}{ Cooperative society } & 12 & 27.3 & & & & \\
\hline \multicolumn{2}{|c|}{ The First Sharq Company } & 1 & 2.3 & & & & \\
\hline \multicolumn{2}{|c|}{ Farm in Al Karameh } & 4 & 9.1 & & & 1 & $\mathbf{5 0 . 0}$ \\
\hline \multicolumn{2}{|c|}{ Kafa'a project } & $\mathbf{1}$ & 2.3 & & & & \\
\hline \multicolumn{2}{|l|}{ Egypt } & 19 & 43.2 & 1 & 100.0 & 1 & $\mathbf{5 0 . 0}$ \\
\hline \multicolumn{2}{|c|}{ Philippine } & $\mathbf{1}$ & 2.3 & & & & \\
\hline \multicolumn{2}{|c|}{ Average of price at purchasing } & \multicolumn{2}{|c|}{10} & \multicolumn{2}{|l|}{10} & \multicolumn{2}{|c|}{$\mathbf{1 3 7 5 . 5}$} \\
\hline \multicolumn{2}{|c|}{ Average production quantity (kg) } & \multicolumn{2}{|c|}{21077.8} & \multicolumn{2}{|l|}{2560} & \multicolumn{2}{|c|}{4250} \\
\hline
\end{tabular}


means that the most common type of fodder used is the concentrated.

Table (17): Type of fodder used.

\begin{tabular}{|l|l|l|}
\hline Type & Frequency & Percentage \\
\hline Floated & 9 & 19.15 \\
\hline Concentrated & 37 & 78.72 \\
\hline $\begin{array}{l}\text { Mixture (32\% } \\
\text { protein) }\end{array}$ & 1 & 2.13 \\
\hline
\end{tabular}

Table (18) explained the sources of obtaining fodder. The results showed that the common source of fodder was from Amman or cooperative societies for the concentrated fodder. The quantity used of the concentrated fodder was 25 tons and the price of it is less than the other two types. The price of one ton of concentrated fodder is JD 233 compared to JD 404 for the floated fodder and JD 400 for the mixture fodder (32\% protein). The low price of concentrated fodder made it more common among farmers.

\subsection{Common Diseases}

Diseases are common among fish which is very sensitive to diseases that if the protection was not effective, the mortality among fish will be very high. This factor is considered one of the obstacles that stopped many farmers to produce fish in Jordan. The high losses caused by high mortality makes it intolerable for the farmers and lead them to quit fish production.

Table (19) showed that the common diseases that could affect fish are fungi and bacteria. Only 4 farmers indicated that the disease that affects fish is of fungi with a percentage $66.7 \%$, while only 2 farmers indicated that the source of infection was bacterial. The low responds for this part reflected the low experience of farmers in fish diseases. So, the lack of experience in fish diseases made many farmers keep away from fish production. This side needs much effort of the formal directories and the private sector to educate farmers about the common diseases in fish.

Table (18): Use and source of fodder.

\begin{tabular}{|c|c|c|c|c|c|c|}
\hline Characteristic & \multicolumn{2}{|c|}{ Floated fodder } & \multicolumn{2}{|c|}{ Concentrated } & \multicolumn{2}{|c|}{$\begin{array}{c}\text { Mixture (32\% } \\
\text { protein) }\end{array}$} \\
\hline Quantity used (Ton) & \multicolumn{2}{|l|}{1.43} & \multicolumn{2}{|l|}{25} & \multicolumn{2}{|l|}{1} \\
\hline Price (JD/Ton) & \multicolumn{2}{|l|}{404} & \multicolumn{2}{|l|}{233} & \multicolumn{2}{|l|}{400} \\
\hline Transportation cost & \multicolumn{2}{|l|}{20} & \multicolumn{2}{|l|}{6.5} & \multicolumn{2}{|l|}{--} \\
\hline Source of fodder & Freq. & Per. & Freq. & Per. & Freq. & Per. \\
\hline Hashemite box & 5 & 55.6 & 1 & 2.7 & & \\
\hline Cooperative society & 1 & 11.1 & 14 & 37.8 & 1 & 100.0 \\
\hline From the farm & 1 & 11.1 & & & & \\
\hline Farm in Karameh & 1 & 11.1 & 2 & 5.4 & & \\
\hline Amman & 1 & 11.1 & 19 & 51.4 & & \\
\hline Ghor & & & 1 & 2.7 & & \\
\hline \multicolumn{7}{|c|}{ Period of adding fodder } \\
\hline Three months & 2 & 28.6 & 1 & 2.8 & & \\
\hline Six months & 5 & 71.4 & 16 & 44.4 & 1 & 100.0 \\
\hline Continuous & & & 19 & 52.8 & & \\
\hline
\end{tabular}

In the case of concentrated fodder, higher number of farmers indicated that the addition occurred for six months or continuously. The number of farmers indicated that the fodder added every six months is 16 with a percent of $44.4 \%$ and the number of farmers added concentrated fodder continuously was 19 farmers with a percent of $52.8 \%$ (Table 17).
None of the farmers responding reflected their sharp knowledge about fish diseases. Some farmers indicated that the time of infection was in winter while others indicated the time of infection was in summer. Some farmers showed that the source of infection was due to the low temperature while the others indicated the high temperature. Some farmers indicated that they diagnose the disease by themselves. Only one 
farmer indicated that the veterinarian was the one who diagnosed the disease (Table 19).

Table (19): The diseases that affect fish breeding.

\begin{tabular}{|l|c|c|}
\hline \multicolumn{1}{|c|}{ Disease } & Frequency & Percentage \\
\hline Fungi & 4 & 66.70 \\
\hline Bacteria & 2 & 33.30 \\
\hline
\end{tabular}

Most of farmers indicated that the symptoms of disease appeared in the form of spots on the fish skin and only one farmer indicated that symptoms were fungi on the fish skin. Concerning the method of treatment, each farmer suggested one method. The suggested methods were heating water, the other moving water continuously, the third adding protein, antibiotics, and changing water continuously. Two farmers indicated that they shoulder the curing process of fish Table (20).

\subsection{Causes of leaving fish farming}

Table (21) showed the causes that many farmers left fish farming. The causes were different from one farmer to another. The major cause in common was the marketing of fish. This factor was considered one of the most important factors because good marketing indicates good prices and high revenues. Also, the spoiling of fish is very fast specially when it is transported under high temperature conditions. So, the farmers seek good marketing channels to assure the freshness of fish and accomplishing the highest prices, too.

The other problem was the low prices compared to the production costs. Under low prices the revenues of farmers will be low and the risk of breeding fish is very high, so the farmer will decide to quit this activity if it is not very feasible for him. The high prices of fodder makes the inputs cost high and so decreasing the revenues of farmers.

Table (20): Characteristics of infection.

\begin{tabular}{|l|l|l|l|l|}
\hline \multirow{2}{*}{ Feature } & Fungi & \multicolumn{3}{l|}{ Bacteria } \\
\cline { 2 - 5 } & Freq. & Per. & Freq. & Per. \\
\hline Time of infection & & & & \\
\hline Winter & 2 & 50.0 & 2 & 100.0 \\
\hline Source of infection & 2 & 50.0 & 0 & 0.0 \\
\hline Low temperatures & & & & \\
\hline High temperatures & 2 & 50.0 & 1 & 50.0 \\
\hline Both & 2 & 50.0 & 0 & 0.0 \\
\hline Diagnosis & 0 & 0.0 & 1 & 50.0 \\
\hline Personally & & & & \\
\hline Veterinarian & 3 & 75.0 & 2 & 100.0 \\
\hline Symptoms & 1 & 25.0 & 0 & 0.0 \\
\hline Fungi on skin & & & & \\
\hline Spots on skin & 1 & 25.0 & 0 & 0.0 \\
\hline Sudden mortality & 3 & 75.0 & 1 & 50.0 \\
\hline Treatment & 0 & 0.0 & 1 & 50.0 \\
\hline Heating water & & & & \\
\hline Moving water continuously & 1 & 16.7 & 0 & 0.0 \\
\hline Protein & 1 & 16.7 & 1 & 33.3 \\
\hline Antibodies & 1 & 16.7 & 0 & 0.0 \\
\hline Water storage & 1 & 16.7 & 1 & 33.3 \\
\hline Changing water continuously & 1 & 16.7 & 0 & 0.0 \\
\hline Curer & 1 & 16.7 & 1 & 33.3 \\
\hline Personally & & & & \\
\hline & 2 & 100.0 & 0 & 0.0 \\
\hline
\end{tabular}


Table (21): The causes of quitting fish farming.

\begin{tabular}{|l|c|c|}
\hline Cause & Frequency & Percentage \\
\hline Lack of fodders & 2 & 6.1 \\
\hline Marketing & 7 & 25.0 \\
\hline Lack of guidance & 2 & 6.1 \\
\hline Low prices selling & 4 & 14.3 \\
\hline High prices of fodders & 4 & 14.3 \\
\hline Lack of water & 2 & 6.1 \\
\hline Lack of ponds suitable for fish farming & 1 & 3.6 \\
\hline Lack of finance & 1 & 3.6 \\
\hline Lack of fish lings for purchase & 2 & 7.1 \\
\hline Lack of matching of fingers to the existed ones & 1 & 3.6 \\
\hline Not feasible & 2 & 7.1 \\
\hline
\end{tabular}

Other farmers showed other important factors. Some farmers justified it for the lack of water, fish lings, suitable ponds, guidance, finance, and so feasibility.

Table (22) lists other causes that made the farmers quit the fish farming. The most important cause is the lack of experience. About 36 farmers which constituted the majority of fish farmers in the sample with a percent of $31.3 \%$ indicated their lack of experience in fish farming. This explained that the ability of farmer to manage the fish culture breeding process under exceptional conditions was very low. Also, farmers once more gave attention to the lack of water as one of the serious problems and the lack of ponds. These two components are very basic components of the production inputs in fish farming.

Fear of failure, lack of time, high inputs cost, lack of fish lings, low production and the financial causes are all considered factors that make many farmers quitting fish farming in Jordan.

\subsection{The production function model}

The historical data collection showed that the number of fisheries increased from 17 in 2008 to 34 farms in 2015 Table (23). The humble increase of farms resulted from farmers' selfefforts to invest in this sector. The increase of the number of farms compensates only very small ratio of the local needs for fish. The producing farms deal with limited number of consumers specifically the restaurants. Dealing and managing this sector nationally is not accomplished till now.

The increase of the value of production was fluctuating over years. The highest increase in value of production was in 2012 with percentage of change reached $43.70 \%$, while the lowest change was recorded in 2013 with a

Table (22): The causes of not practicing fish farming.

\begin{tabular}{|l|l|l|}
\hline Causes of not practicing fish farming & Frequency & Percentage \\
\hline Lack of experience & 36 & 31.3 \\
\hline Lack of water & 8 & 7.0 \\
\hline Lack of ponds & 10 & 8.7 \\
\hline Fear of failure & 2 & 1.7 \\
\hline Fear of deteriorating the pond & 2 & 1.7 \\
\hline Lack of time for fish farming & 3 & 2.6 \\
\hline Lack of encouragement of formal directions & 3 & 2.6 \\
\hline Marketing problems & 1 & 9.0 \\
\hline Lack of fish & 3 & 2.6 \\
\hline Lack of information about fish farming & 3 & 2.6 \\
\hline High cost inputs & 9 & 7.8 \\
\hline Theft & 9 & 7.8 \\
\hline Lack of regular support of water & 3 & 2.6 \\
\hline Low production & 1 & 9.0 \\
\hline Financial causes & 22 & 19.1 \\
\hline
\end{tabular}


decrease $0.61 \%$. The fluctuation of value of production resulted from the instable inputs of this industry. of availability of water as a core input in this industry. The results showed that most of farmers who have fish farming are practicing

Table (23): The economics of aquaculture farms in Jordan.

\begin{tabular}{|l|l|l|l|l|l|l|}
\hline Year & $\begin{array}{l}\text { Number } \\
\text { of farms }\end{array}$ & $\begin{array}{l}\text { Value of } \\
\text { physical } \\
\text { inputs in } \\
\text { aquaculture }\end{array}$ & $\begin{array}{l}\text { Compensation } \\
\text { of labor in } \\
\text { aquaculture }\end{array}$ & $\begin{array}{l}\text { Value of } \\
\text { other } \\
\text { expenses }\end{array}$ & $\begin{array}{l}\text { Value of } \\
\text { production }\end{array}$ & Change \\
\hline 2008 & 17 & 850579.5 & 58290 & 4330 & 1279800 & \\
\hline 2009 & 17 & 1054101 & 97745 & 54867 & 1654673 & 29.29 \\
\hline 2010 & 23 & 858132 & 151245 & 27355 & 1884564 & 13.89 \\
\hline 2011 & 23 & 1107366 & 217520 & 36981 & 2426010 & 28.73 \\
\hline 2012 & 27 & 1070666 & 273420 & 33668 & 3486110 & 43.70 \\
\hline 2013 & 27 & 1519324 & 335450 & 49327 & 3464735 & -0.61 \\
\hline 2014 & 28 & 1272645 & 305510 & 40373 & 3875381 & 11.85 \\
\hline 2015 & 34 & 1631567 & 250430 & 81735 & 4109975 & 6.05 \\
\hline
\end{tabular}

Table (24) showed that there is a correlation between the inputs of farming indicating that there is autocorrelation among independent variables. So, the effect of input variables on production will be analyzed separately to remove the effect of autocorrelation. other agricultural activities. This might resulted from the lack of experience in one direction, or the high problems associated with fish production in Jordan. This is justified by the low number of farmers practicing fish farming which formed less than half of the sample.

Table (24): Correlation matrix of economic of aquaculture.

\begin{tabular}{|l|l|l|l|l|}
\hline & Physical inputs & $\begin{array}{l}\text { Compensation of } \\
\text { labor }\end{array}$ & Other expenses & Production \\
\hline Physical input & 1 & $0.728^{*}$ & $0.722^{*}$ & $0.828^{*}$ \\
\hline $\begin{array}{l}\text { Compensation } \\
\text { of labor }\end{array}$ & & $0.709^{*}$ & $0.942^{* *}$ \\
\hline Other expenses & & & & 0.692 \\
\hline
\end{tabular}

The results showed high significant contribution of compensation of labor to the production value, followed by the effect of physical inputs. The effect of other expenses was not significant on the production value.
Considerable percentage of farmers indicated that they practice fish production to increase their income, while others introduced other justifications. Most of farmers encouraged to Enter this experience as the basic inputs are

Table (25): The effect of inputs value on fish production value.

\begin{tabular}{|l|l|l|l|l|l|}
\hline Source of variation & $\mathrm{R}^{2}$ & $\mathrm{~F}$ & Constant & Coefficient & t-value \\
\hline Physical inputs & 0.685 & 13.04 & -6.441 & 1.520 & $3.611^{*}$ \\
\hline $\begin{array}{l}\text { Compensation of } \\
\text { labor }\end{array}$ & 0.887 & 47.02 & 6.618 & 0.671 & $6.857^{*}$ \\
\hline Other expenses & 0.479 & 5.511 & 11.178 & 0.344 & 2.348 \\
\hline
\end{tabular}

\section{Discussion}

This research aimed at investigating the production economics of fish in Jordan. The sample covered the three regions north, middle and south. The results showed that the distribution of fish farming was more in the northern and middle regions compared to the southern regions. This distribution was a result available at their farms including raising ponds and water used for other agricultural purposes. This was justified by the low number of farmers that rely on fish income as a source.

Most farmers were using the available water sources for fish production despite its suitability for production. This increases the exposure of risk in fish production. This appears through the 
farmers evaluation of water quality for fish production, who indicated that water quality is one of the constrains for fish production. The procedures used in production in such environment are tolerable for simple breeding and diseases which decrease the effort made by farmers through the breeding process. The most species used was Tilapia. The problems faced by the farmers were concentrated and distributed on different directions. The major concentration was on marketing. The lack of economic production made marketing a major issue in production. The other problems were distributed on other activities.

Farmers of the sample indicated different causes that may lead them to leave this industry. The most important factors was the lack of marketing as a measure problem, the high inputs prices and the low profit made from this industry. Wide proportion of the sample who do not practice fish farming indicated that the lack of experience is one of the causes that made them away from practicing this industry.

The production function analysis indicated that the profit made from this industry for farmers is acceptable but it is not enough to encourage other farmers to join this industry. The contribution and the effect of inputs on income make it urgent to discuss the different variables that contribute to improve these elements to decrease the cost of inputs and maximize the profit with the existence of good marketing channels.

\section{Conclusion and Recommendations}

According to the previous results of both sources of data, the followings can be concluded:

1. The production of fish is very important activity as the major source of fish is the imported one.

2. The inputs of fish production are not available inside Jordan with logic prices for the production process.

3. Lack of proper marketing channels makes an obstacle for farmers to increase their production of fish.

4. Fish breeding holding did not reach the feasible size as many farmers are not relying on fish production as a major source of income.

5. Lack of water is considered one of the constraints of fish production in Jordan.

6. The low experience of fish farming is considered one of the obstacles that face farmers in managing the production process.
7. The introduced guidance for farmers is not enough to make them more capable of improving their production.

8. The veterinary services available for farms are very low to cover the requirements of fish farms.

9. Fodder availability is very low and its prices very high.

10. The lack of fish lings required for the production process.

This research recommend farmers to join this industry despite the low profits gained but with time the enrichment of experience and the enlargement of this sector will improve experience and shift the care of private and public sector to provide inputs with more reasonable prices. The expanding of production on the other hand horizontally and vertically by farmers will increase the profitability of this industry. National awareness program required to enhance the satisfaction of farmers to invest in this sector.

\section{REFERENCES}

Department of Statistics (2009-2016). Agricultural Statistics Report, Agricultural National Development Surveys. Amman, Jordan.

Department of Statistics, (2015). Animal Production Division, Amman, Jordan

FAO (2003). Fish production in Jordan. http://www.fao.org/fi/oldsite/FCP/en/JOR/ profile.htm

FAO (2014). FAO Fishery Department Country Profile. Jordan, Available Dec., 2014.

Hamidan, N. (2014). Fish species assemblages in two riverine systems on Mujib Basin in Jordan and the effects of impoundment. Jordan J. of Biol. Sci., Vol. 7(3): 179-185.

New Partnership for African Development, (NEPAD) 2005. Action Plan for the Development of African Fisheries and Aquaculture. Report of NEPAD Fish For All Summit, Abuja.

Olaoye O. J, Ashley-Dejo S. S, Fakoya E. O, Ikeweinwe N. B, Alegbeleye W. O, Ashaolu, F.O and Adelaja O. A. (2013). Assessment of socio-economic analysis of fish farming in Oyo State, Nigeria. Global J. Sci. Fron. Res. Agric. and Vet. 13 (9): 44-55. 


$$
\begin{aligned}
& \text { اقتصادات تربية الأسماك في الأردن } \\
& \text { جو اد عاطف الضلاعين } \\
& \text { قسم العلوم التربوية والاجتماعية ـ كلية الكرك الجامعية ـ جامعة البلقاء التطبيقية ـ الأردن }
\end{aligned}
$$

بدأ إنتاج الأسماك كتجارب لاختبار الطرق و المنهجيات في الأردن. عملية تسويق السمك من العمليات المعقدة وتعتمد على طبيعة

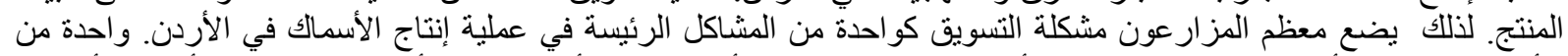

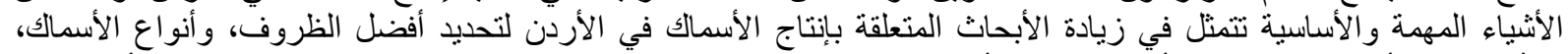

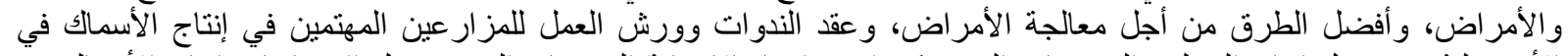

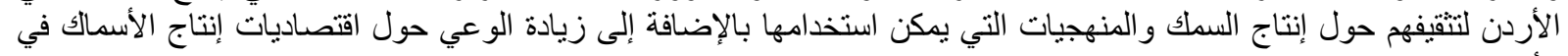

المجلة العلمية لكلية الزراعة جالزمعة القاهرة ـ المجلد (67) العدد الثانى (ابريل 2016 ) : 121-109. 